\title{
COMPARATIVE CHARACTERISTIC OF LUNG CANCER STEM-LIKE CELLS GENERATED IN VITRO UNDER DIFFERENT CULTURE CONDITIONS
}

\author{
O. V. SKACHKOVA ${ }^{1 凶}$, O. I. GORBACH ${ }^{1}$, M. V. INOMISTOVA ${ }^{1}$, \\ L. V. GARMANCHUK ${ }^{2}$, N. M. KHRANOVSKA ${ }^{1}$ \\ ${ }^{1}$ National Cancer Institute, Kyiv, Ukraine; \\ ${ }^{2}$ ESC "Institute of Biology and Medicine", \\ Taras Shevchenko National University of Kyiv, Ukraine; \\ @e-mail: oksanaskachkova@ukr.net
}

Received: 20 June 2020; Accepted: 17 December 2020

\begin{abstract}
Cancer stem cells (CSCs) play an important role in resistance to cancer treatment and recurrence developing. The aim of this study was to obtain cell culture of MOR line non-small cell lung cancer cells enriched in CSCs and to investigate its functional and molecular-genetic properties. Tumor spheroids (TS) of MOR cell line were generated in vitro under normal adhesive (0.2\% carboxymethyl cellulose, CMC) or low-adhesive (2\% agarose) culture conditions. Lateral population of TS was evaluated by flow cytometry with the use of R-123 fluorescent dye, the index of R-123 exclusion was also assessed. Expression of CD44, ALDHA1, CD133, SOX2 and NANOG mRNA was determined with RT-qPCR. It was found that regardless of the culture conditions tumor spheroids form a lateral population characterized by an increased dye exclusion index. Expression levels of CD44, ALDHA1, CD133, SOX2 and Nanog mRNA in TS cells obtained under lowadhesive (2\% agarose) conditions were significantly higher than in monolayer cells and cells obtained using $0.2 \%$ CMC. Thus, the proposed method of culturing in low-adhesive conditions allowed to enrich significantly tumor spheroids of MOR line in cells with CSC properties.
\end{abstract}

Keywords: cancer stem cells, non-small cell lung cancer, spheroids, MOR cell line, CD44, ALDHA1, CD133, SOX2, NANOG.

$\mathrm{A}$ ccording to WHO more than 2 million new lung cancer (LC) are detected in the world. Moreover, $61.1 \%$ of first time cancer identified patients did not live more than 1 year [1]. High lung cancer morbidity is observed in Ukraine, namely almost 12.54 thousand of new cases were detected in 2018 while at the same time 9.53 thousand patients were died according to the bulletin of National Chancer-Registry of Ukraine [2].

Combined approaches are considered to be the "standard" of treatment for patients with LC that include radical surgery, chemotherapy and radiation therapy. However, the recurrences and metastases may occur in $30-50 \%$ of patients including early stages [3]. The risk of recurrences and metastases after the combined treatment mainly determined with population of cancer stem cells (CSCs) that are resistant to radiation and chemotherapy [4]. CSCs make up less than $1 \%$ of all tumor cells, but are able to significantly affect the disease course [5]. CSC biology has widely investigated in the most common malignancies past 20 years. The CSC exceptional plasticity and the complexity of the processes are promoting the development of new methods of their purification and approaches for "therapy" targeted to CSCs [6].

According to CSC theory only population of these cells has tumorogenic properties and is capable to support tumor growth and tumor metastasis [7]. Considering the processes associated with the properties of CSC, it becomes relevant the development of new therapeutic treatment strategies, name-

(C) 2021 Skachkova O. V. et al. This is an open-access article distributed under the terms of the Creative Commons Attribution License, which permits unrestricted use, distribution, and reproduction in any medium, provided the original author and source are credited. 
ly: stimulation of CSC differentiation, destruction of physiological niches, inhibition of migration ability and CSC chemoresistance, normalization of the immune response and the development of methods for personalized anti-CSC immunotherapy. The antiCSC therapy is a new, promising strategy in oncology as it allows us to move away from old, established perceptions of the cancer pathogenesis. Investigation mRNA expression of the stemness genes and functional properties of CSCs in tumor cell lines may serve as a laboratory model for finding the effectiveness of new treatments.

Aim. To obtain MOR non-small cell lung cancer (NSCLC) cell culture enriched CSCs and to investigate its functional properties and expression of the stemness genes.

\section{Materials and Methods}

Cultural works. We used MOR non-small cell lung cancer cell line (ECACC, UK). Cells in the amount of $1.35 \times 10^{6}$ were placed in T25 culture flasks (TPP, Switzerland) in complete culture medium, which included DMEM (Gibco, USA), 10\% ETC (Gibco, USA), 2 mM L-glutamine (Gibco, USA) and a mixture of $100 \mathrm{U}$ penicillin and $0.1 \mathrm{mg} /$ $\mathrm{ml}$ streptomycin (Gibco, USA). Cells were cultured in a $\mathrm{CO}_{2}$ incubator at $37^{\circ} \mathrm{C}$ and $5 \% \mathrm{CO}_{2}$ atmosphere, cell culture was checked daily for growth patterns, confluence and color change of the culture medium. When the medium was changed to yellow, $75 \%$ culture medium was replaced.

Generation of tumor spheroids. TS were obtained in two ways. In the first way, $0.2 \%$ carboxymethylcellulose (CMC) was used. For this purpose, MOR tumor cell line in the amount of $1.35 \times 10^{6}$ was introduced into T25 culture vials in complete culture medium with the addition of 0.2\% CMC (Sigma, USA) [8]. In the second way, a culture plate with a standard adhesive surface was pre-coated with a $2 \%$ agarose solution (AppliChem, Germany) prepared on distilled water [9]. Cells were cultured in a $\mathrm{CO}_{2}$ incubator at $37^{\circ} \mathrm{C}$ and $5 \% \mathrm{CO}_{2}$ atmosphere cell culture was checked daily for growth patterns and formation of spheroids that were in the thickness of the culture medium. Cytometric and molecular-genetic analysis were performed on the 6th day of cultivation.

Flow cytometric studies. To investigate the side population (SP) of CSC, cells in the amount of $3 \times 10^{6}$ were added to $2 \mathrm{ml}$ of Rhodamine 123 (R-123) (100 ng/ml) solution (Sigma, USA), incubated for $30 \mathrm{~min}$ at $37^{\circ} \mathrm{C} .4 \mathrm{ml}$ of cold DPBS was added to the suspension of cells with R-123, the cells were centrifuged at $1000 \mathrm{rpm}$ for $5 \mathrm{~min}$. The cell pellet was resuspended in $0.5 \mathrm{ml}$ of DPBS and left for $30 \mathrm{~min}$ at $37^{\circ} \mathrm{C}$. The residual fluorescence of cells with R-123 was determined by flow cytometry, the activation of the dye was performed by a laser with $488 \mathrm{~nm}$ wavelength, the fluorescence was determined using a 530/30 nm filter [10].

The level of cell line resistance was characterized using the R-123 exclusion index (REI). REI values were defined as R-123 mean fluorescence value in the tumor cells suspension to the fluorescence intensity of cells that excluded R-123. Samples were analyzed on a FACSCalibur flow cytometer (Becton Dickinson, USA) equipped with two lasers (488 and $625 \mathrm{~nm}$ ) using CellQuest-PRO for Mac computers.

Quantitative polymerase-chain reaction $(q P C R)$. Total RNA from TS was isolated using "Ribo-prep” reagents (Amplisens, Russia) according to the manufacturer's protocol. Reverse transcription reaction was performed with "Reverta-L100" assay kit (Amplisens, Russia) according to the manufacturer's protocol. Gene mRNA expression was determined by qPCR with real-time detection on 7500 Real-Time PCR Systems (Applied Biosystems, USA) using specific primers for CD44, ALDH1, CD133, SOX2 and NANOG genes and fluorochrome SYBRGreen (Termo Scientific, USA). The primer and probe sequences were selected using Primer Express ${ }^{\circledR}$ Software v3.0 and synthesized by Applied Biosystems (USA). Glyceraldehyde-3-phosphate dehydrogenase (GADPH) was used to normalize levels of mRNA for the relative quantification method of analysis. Forward and revers primers were used at 5 pM concentrations. Reaction mixture $(25 \mu \mathrm{l})$ was contained $0.25 \mu \mathrm{l}$ of each primer, $12.5 \mu \mathrm{l}$ Maxima SYBR Green/ROX qPCR Master Mix (Applied Byosystems, USA), $7 \mu$ deionized $\mathrm{H}_{2} \mathrm{O}$ and $5 \mathrm{ng}$ of cDNA. 45 cycles real-time PCR $\left(94^{\circ} \mathrm{C}-15 \mathrm{sec}\right.$, $60^{\circ} \mathrm{C}-15 \mathrm{sec}$ and $72^{\circ} \mathrm{C}-30 \mathrm{sec}$ ) were run on 7300/7500 Real-Time PCR Systems, "Applied Biosystems", USA. Calculations were performed using the $2^{-\mathrm{ACt}}$ relative quantification method. mRNA expression value was calculated by the formula:

$$
\mathrm{x}=2^{-\Delta \mathrm{Ct}} \text {, }
$$

where $\mathrm{x}-$ mRNA expression value, $\Delta \mathrm{Ct}=\mathrm{Ct}$ (GAPDH) - Ct (target gene).

Statistical analysis. Gaussian distribution of the group was checked with Shapiro-Wilk test. Statistical analysis included Mean \pm SE for Gaussian dis- 
tribution and Median \pm Percentiles $\left(\mathrm{Q}_{1}\right.$ and $\left.\mathrm{Q}_{3}\right)$ for non-parametric data. To compare the data in three groups, we used One-way ANOVA with Tukey posthoc test for Gaussian distribution and Kruskal-Wallis test for nonparametric ones. Null-hypothesis of variables equality was rejected when $P<0.05$. Statistical analysis was performed using Statistica 10.0 software package (Stasoft Inc., USA).

\section{Results and Discussion}

The small number of SCs in the tumors causes the problem of finding their specific markers. With the development of flow cytometric approaches, it has become possible to identify specific markers of CSCs, namely CD44, CD133, OCT4, SOX2, NANOG, ALDH1, CXCL12 [11], which allow isolating and characterizing these cells. Spheroid cell culture is used as a method of CSCs enrichment, which is based on their ability to grow without attachment to the substrate. Some researchers use the multicellular spheroid culture to enrich and maintain the CSC subpopulations for different cancer types [12]. Spheroid-forming cells feature stem-like properties and express CSC markers [13]. Cancer cell sources for the formation of TS may be different, but the general procedure for enriching CSC in vitro based on the unique ability of SC to survive and grow in spherical structures with limited nutrient intake conditions. So tumor cells do not receive enough nutrients and some of them will be dying, but stem-like cells feel adverse conditions and multiply by asymmetric division with production of growth factors. The main feature of such TS is the enrichment of tumor population with cells that have the characteristics of CSC [14].

We conducted a series of in vitro experiments using MOR line of NSCLC (ECACC, UK). MOR is adhesive tumor cells and able to form PS on the 6 culture day in the $0.2 \%$ CMC or $2 \%$ agarose conditions. The cells formed aggregates of irregular shape which varied greatly in size after culture in $2 \%$ agarose. The diameter of the largest aggregates was $30-100 \mu \mathrm{m}$ in $0.2 \%$ CMC culture and $60-140$ $\mu \mathrm{m}$ in $2 \%$ agarose culture on the 6 culture day. One of the CSC detection methods is a functional test that allows evaluating the exclusion efficiency of fluorescent dyes from cells, such as R-123 and Hoechst 33342 [15]. CSCs have ability to exclude these dyes due to the high expression of the cell membrane transporters, including various proteins of the $\mathrm{ABC}$ family. The CSC population with excluded
R-123 is called SP. For a number of malignant tumors, CSCs in SP is characterized by high tumorigenic activity in immunodeficient mice transplantation, the ability to self-renew, differentiate and reproduce morpho-functional heterogeneity of the tumor. Therefore, one of the study tasks was to identify SP of the CSCs and determine their content using a functional test that characterizes the activity of transporter proteins.

Our studies have shown that TS generation method statistically significantly affected the SP cell amount ( $\mathrm{F}=4.74, P=0.022$; Fig. 1 and Fig. 2). According to Tukey's HSD test, the using of $0.2 \%$ CMC led to a statistically significant increasing in 2.18 times the number of SP cells compared to cells in monolayer ( $P=0.03$; Fig. 2$)$. Number of SP cells obtained in $2 \%$ agarose conditions also increased 1.64 times compared to adhesive cells.

The average fluorescence level (GeoMean) in SP cells did not change significantly in all groups whatever from the cell culturing conditions. Analysis of REI showed that different culture conditions (adhesive cells, $0.2 \%$ CMC or $2 \%$ agarose) statistically significantly influence on REI in MOR cells ( $\mathrm{F}=5.27, P=0.017$ ). Moreover, after applying of Tukey's HSD test we found a statistical difference of REI between SP obtained with $0.2 \% \mathrm{CMC}$ and $2 \%$ agarose $(P=0.007)$. Therefore, MOR cells in SP characterized by an increasing of REI on the 6 culture day regardless of the culture conditions (by adding $0.2 \%$ CMC or $2 \%$ agarose).

The next task was to determine the effect of different in vitro culture conditions on mRNA expression of the stemness genes of MOR cells. Namely, the expression of $C D 44$ and $C D 133$ surface markers, NANOG and SOX2 transcription factors and ALDH1 enzyme were studied in MOR cell TS (Fig. 3 and Fig. 4).

CD44 is an adhesive protein that participates in cell-cell and cell-intercellular matrix interactions through to the hyaluronic acid. CD44 molecule is also involved in lymphocyte recirculation, lymphocyte activation, myelopoiesis, lymphopoiesis, and angiogenesis [16]. CD44 is considered a CSC marker in some solid tumors, including breast, pancreas, head and neck, hepatocellular liver cancer, non-small cell lung cancer and colon cancer [17]. CD44+ colon CSCs show greater tumorigenicity and the ability to form colonies in vitro compared to CD44- colon CSCs. CD133+ adenocarcinoma cells have been shown to be resistant to cisplatin and 

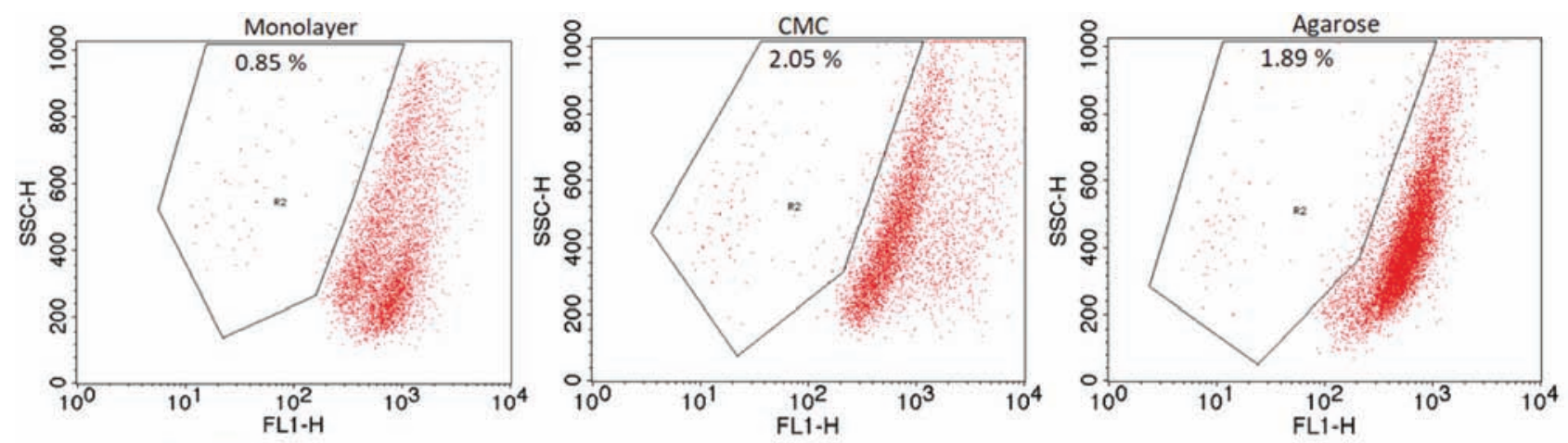

R-123

Fig. 1. The SP cells after R-123 exclusion by MOR cells obtained under different conditions
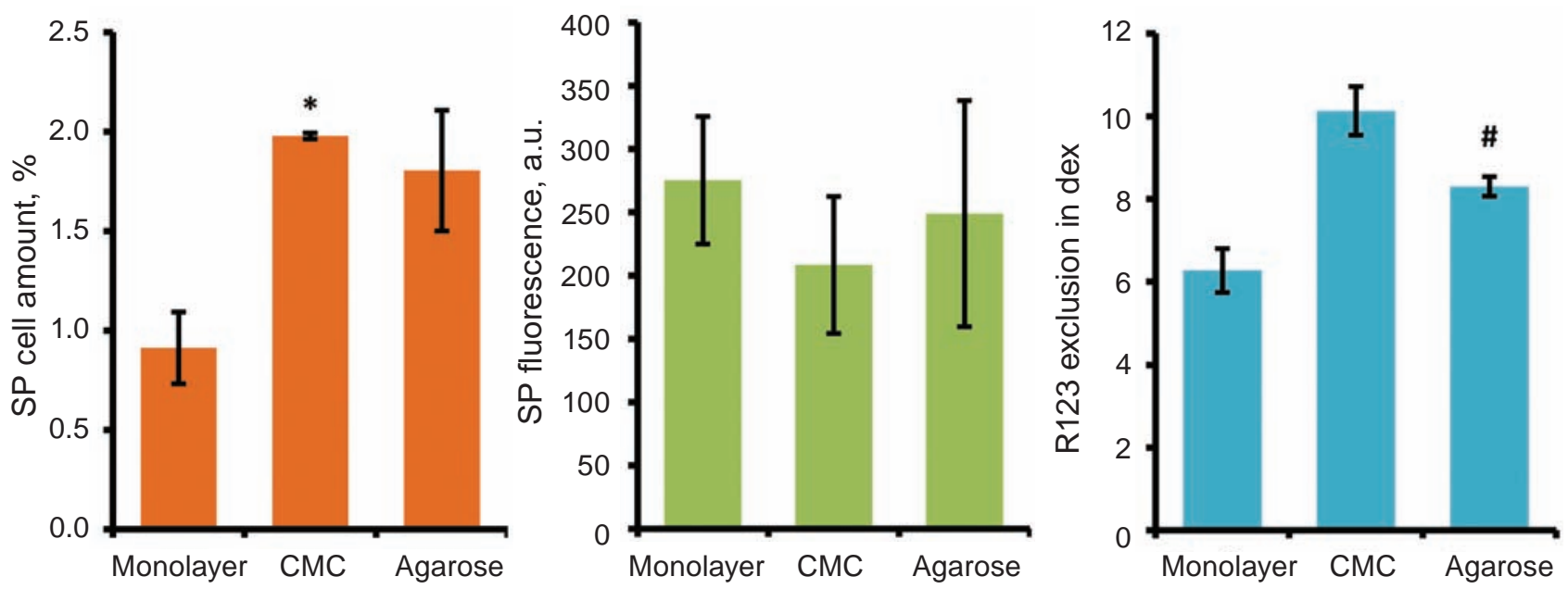

Fig. 2. The exclusion effect of the fluorescent dye R-123 by SP cells of MOR cell line $(n=10) ; * P<0.05$ compared to the value in the monolayer group; ${ }^{\# P}<0.05$ - compared to the value in cells under $0.2 \% C M C$
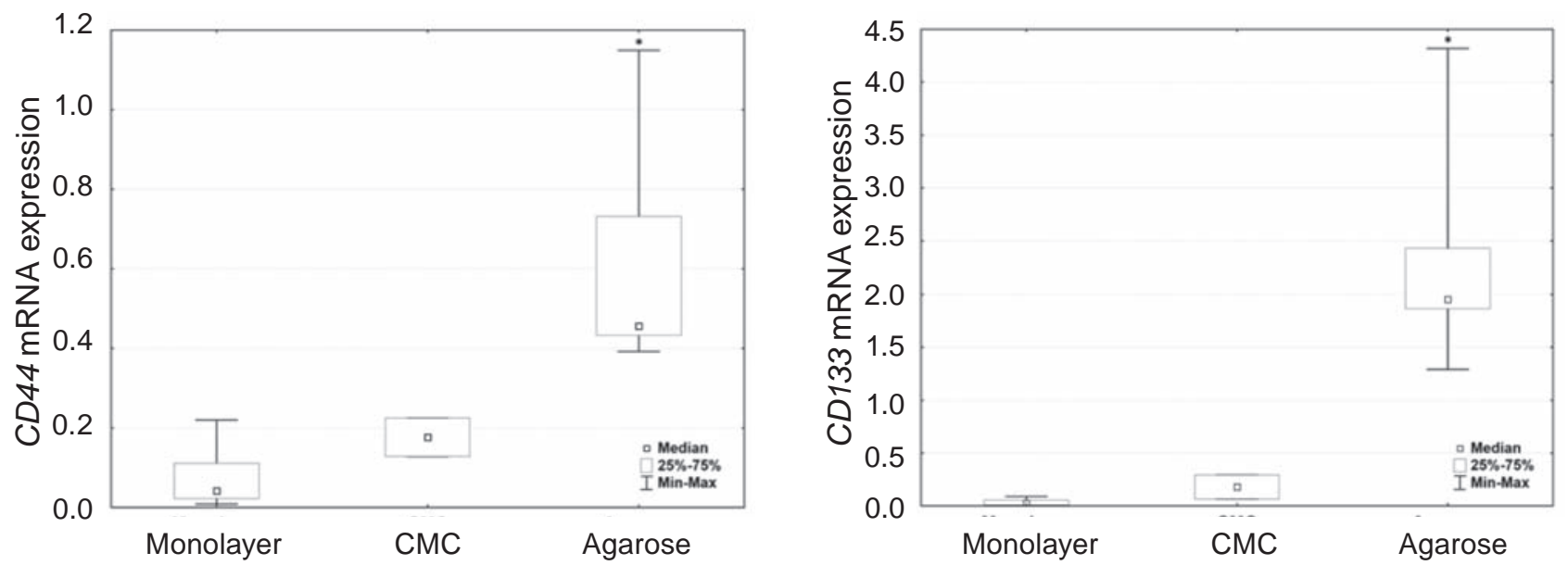

Fig. 3. The mRNA expression of CD44 and CD133 surface markers in MOR cells cultured in different conditions $(n=10) ; * P<0.05$ - compared to monolayer MOR cells 

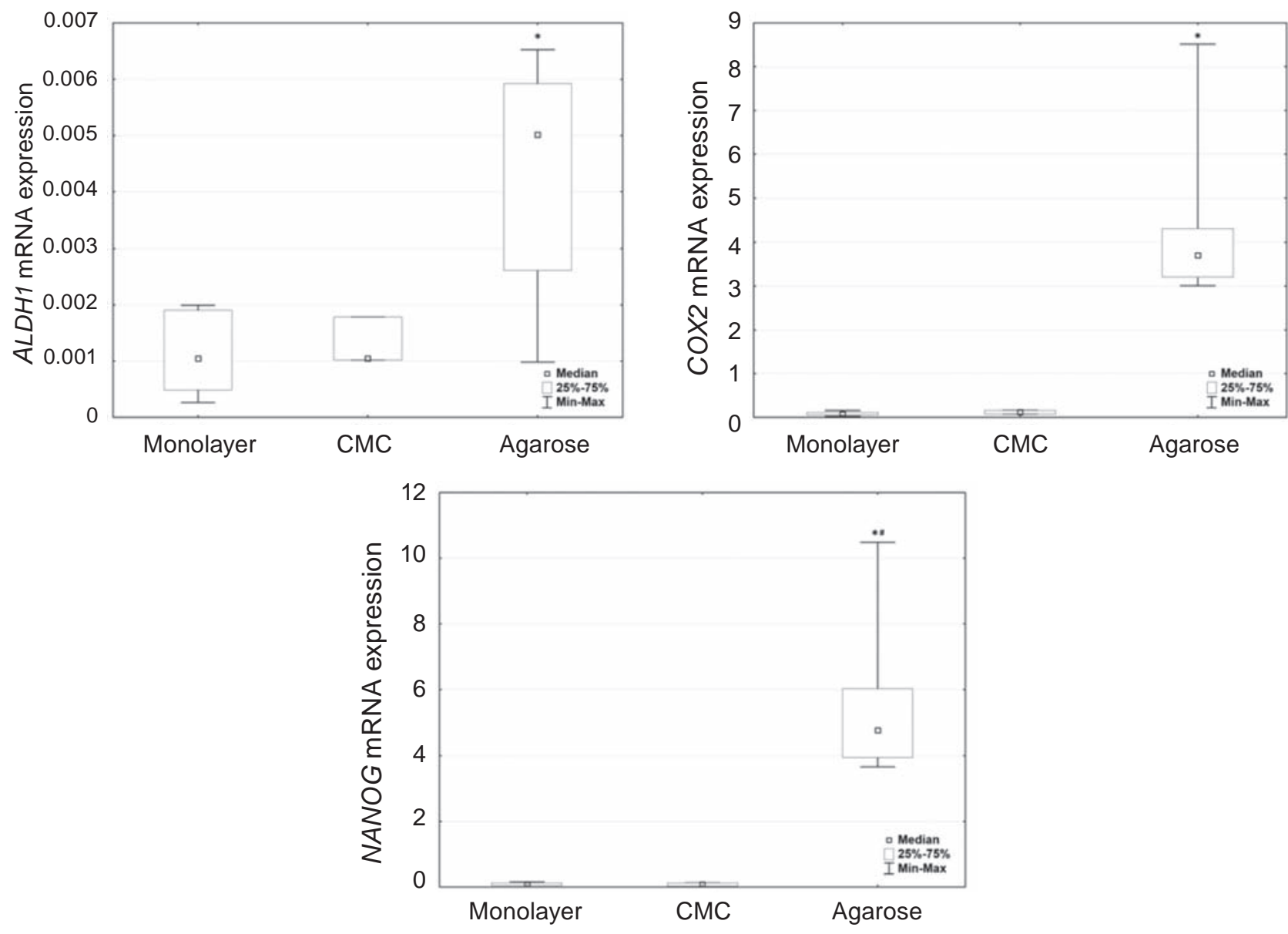

Fig. 4. ALDH1 and transcription factors mRNA expression in MOR cells cultured under different conditions $(n=10) ;{ }^{*} P<0.05$ - compared to $m R N A$ expression value in monolayer cells; ${ }^{*} P<0.05$ - compared to mRNA expression value in cells under $0.2 \%$ CMC

ALDH1+ cells to paclitaxel and taxol. The results of our studies showed that MOR cell TS obtained in low-adhesion conditions ( $2 \%$ agarose) the level of CD44 mRNA expression was in 8.3 times and 3.3 times higher compared to adhesion tumor cells and cells obtained when using $0.2 \%$ CMC respectively ( $\mathrm{H}=15.08, P=0.0005$; Fig. 3). It was also found that $C D 133$ mRNA expression level was 69.9 times and 12.7 times higher in MOR cell TS obtained under low-adhesion culturing conditions compared to adhesive tumor cells, and TS cells obtained using $0.2 \%$ CMC $(\mathrm{H}=15.75, P=0.0004)$. Thus, $C D 44$ and $C D 133$ markers mRNA expression levels in the MOR line TS obtained under low-adhesion culture conditions were significantly higher compared to the values in the cells obtained by other culture methods. The obtained results coincide with the data of the authors who studied the lung cancer CSCs and their characteristics. Same data was obtained Leung
E.L. et al., the subpopulation of CD44+ NSCLC cells were capable of spheroid body formation and in vivo tumor initiation [18]. Hardavella G. et al. showed that co-expression of CD90 further narrowed down the stem cell population as spheroid-forming cells were mainly found within the CD44+ CD90+ subpopulation with expression of mesenchymal markers $\mathrm{N}$ Cadherin and Vimentin, increased mRNA levels of the embryonic stem cell related genes NANOG and OCT4 and increased resistance to irradiation, therefore suggesting the CD44+ CD90+ population as a good candidate for the lung CSCs [19].

The next studied markers were SOX2 and NANOG transcription factors and ALDH1 intracellular enzyme. ALDH1 is a detoxification enzyme that oxidizes intracellular aldehydes and converts retinol into a retinoic acid. Hyperexpression of A $L D H 1$ leads to increased proliferation provides resistance to alkylating agents and protection of stem cells from 
oxidative stress and promotes their existence [20]. ALDH1A1 is one of ALDH 19 isoforms expressed in humans and is considered a specific marker for the identification, isolation, and monitoring of colon CSCs, however, according to some data, ALDH1 is also a marker of common SCs in various tissues [21]. The association of ALDH1 high levels with poor prognosis and metastases in breast cancer patients was noted [22].

Our data showed that mRNA expression level of ALDH1 enzyme in MOR cell TS obtained under low-adhesion culture conditions (2\% agarose) increased in 3.95 times and 3.34 times compared to monolayer and TS obtained under $0.2 \%$ CMC culture conditions respectively $(\mathrm{H}=6.62, P=0.04$; Fig. 4).

In 1994, SOX2 gene as a member of SOX family was also found in humans. It is located on 3q26.3q27 chromosome and encodes a protein consisting of 317 amino acids. SOX2 plays a key role in supporting stem cell populations, determining their death and the necessary factor for reprogramming of somatic cell pluripotency [23].

SOX2 is involved in the development of a large number of malignant neoplasms types and refers to the marker of CSC. It has been established that the presence of SOX2 serves as a prognostic marker in esophageal and lung cancers [24]. The SOX2 high expression is associated with a poor prognosis, short progression free period, low-degree of differentiation, lymph node involvement, T3-T4 stages and distant metastases in colon cancer patients [25]. Therefore, the results of our studies showed that SOX2 mRNA expression level in TS obtained in low-adhesion conditions ( $2 \%$ agarose) much higher compared to adhesive tumor cells and TS obtained by culture with $0.2 \%$ CMC ( $\mathrm{H}=13.47, P=0.0012$; Fig. 4).

It is known that NANOG transcription factor controls the maintenance of the cell pluripotent state and their ability to self-reproduce. NANOG high expression level stimulates tumor growth and metastasis of breast cancer cells [26]. Our studies showed that the using of low-adhesion culture conditions ( $2 \%$ agarose) statistically significant increased NANOG mRNA expression level in TS compared to monolayer and $0.2 \%$ CMC culture conditions ( $\mathrm{H}=11.45, P=0.0033$; Fig. 3 ).

According to the Wefers C. et al., the use of DC vaccines loaded with NANOG-specific anti- gens, which were obtained from TS of tumor lines is a very promising area of immunotherapy for cancer patients [27].

Therefore, the results of our studies showed that CD44, ALDH1, CD133, SOX2 and NANOG mRNA expression levels in TS of MOR line obtained in low-adhesion conditions ( $2 \%$ agarose) significantly exceed the following values in monolayer cells and cells obtained using 0.2\% CMC which are typical for CSC. This approach allows maximally enriching the cell lines with CSC and then using them for antitumor immunotherapy.

It should also be noted that obtaining spheroids from tumor cell lines in vitro is a complex technological process that requires the use of high-cost reagents. As a result of our research, it was found that the use of $2 \%$ agarose allows to partially replace special vials with low-adhesion properties, which are quite expensive, which can significantly reduce the cost of cultural work.

In summary, it can be noted that an important aspect in the study of the biology of CSCs is their special metabolic properties. Cultivation method which allows to enrich the cell population with stem-like cells, will further allow to isolate this CSCs and more detail describe them. Molecular genetic markers not only identify CSCs, but are also important for the manifestation of their properties, as they are associated with the activation of genes and signaling pathways that regulate their stemness, and therefore they are often considered as potential targets for targeted therapy. In turn, a deeper understanding of the molecular and biological characteristics of these cells will make a significant contribution to solving the problem of cancer therapy.

Conflict of interest. Authors have completed the Unified Conflicts of Interest form at http://ukrbiochemjournal.org/wp-content/uploads/2018/12/ coi_disclosure.pdf and declare no conflict of interest.

Funding. This work was supported by a Grant from the Ministry of Health of Ukraine № 0116U002409 “Investigation of the phenotypic, functional and molecular genetic characteristics of tumor cells with stem cell properties and substantiation of their applicability as an immunotherapeutic target”. 


\section{ПОРІВНЯЛЬНА ХАРАКТЕРИСТИКА СТОВБУРОПОДІБНИХ КЛІТИН РАКУ ЛЕГЕНЬ ЗА РІЗНИХ УМОВ КУЛЬТИВУВАННЯ IN VITRO}

\author{
О. В. Скачкова ${ }^{1 \bowtie}$, О. I. Горбач 1 , \\ М. В. Іномістова ${ }^{1}$, Л. В. Гарманчук², \\ Н. М. Храновська ${ }^{1}$
}
${ }^{1}$ Національний інститут раку, Київ, Україна; ${ }^{2}$ ННЦ «Інститут біології та медицини», Київський національний університет імені Тараса Шевченка, Україна; 凶e-mail: oksanaskachkova@ukr.net

Ракові стовбурові клітини (CSCs) відіграють важливу роль у стійкості за лікування раку та розвитку рецидивів. Мета роботи - отримати збагачену на CSCs культуру клітин лінії MOR недрібноклітинного раку легені та

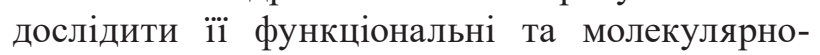
генетичні властивості. Пухлинні сфероїди (ПС) лінії MOR генерували in vitro в стандартних (з додаванням 0,2\% карбоксиметилцелюлози, СМС) або низькоадгезивних (3 2-им\% розчином агарози) умовах культивування. Бокові популяції ПС досліджували методом протокової цитофлуориметрії 3 використанням флуоресцентного барвника R-123, також оцінювали індекс виключення R-123 із клітин. Рівень експресії мРНК генів CD44, ALDHA1, CD133, SOX2 та Nanog визначали методом кількісної ПЛР у режимі реального часу. Встановлено, що незалежно від умов культивування ПС утворювали бокову популяцію зі збільшеним індексом виключення R-123. Виявлено, що рівень експресії мРНК CD44, ALDHA1, CD133, SOX2 та NANOG у ПС лінії MOR, отриманих за низькоадгезивних умов (2\% агарози) вірогідно перевищує відповідні показники в клітинах моношару та клітинах, отриманих за використання 0,2\% СМС. Отже, запропонований метод культивування ПС недрібноклітинного раку легені MOR у низькоадгезивному середовищі дозволяє досягти максимального збагачення на клітини, що мають властивості CSC.

Кл юч ов і слов а: стовбурові пухлинні клітини, пухлинні сфероїди, лінія MOR, CD44, ALDHA1, CD133, SOX2, NANOG.

\section{References}

1. Bray F, Ferlay J, Soerjomataram I, Siegel RL, Torre LA , Jemal A. Global cancer statistics 2018: GLOBOCAN estimates of incidence and mortality worldwide for 36 cancers in 185 countries. CA Cancer J Clin. 2018; 68(6): 394-424.

2. Fedorenko ZP, Michailovich YY, Goulak LO, Gorokh YL, Ryzhov AY, Soumkina O V, Koutsenko LB. Cancer in Ukraine 2018-2019. Bull Nat Cancer Registry Ukraine. 2020; (21): 81 p.

3. Lim E, Baldwin D, Beckles M, Duffy J, Entwisle J, Faivre-Finn C, Kerr K, Macfie A, McGuiga J, Padley S, Popat S, Screaton N, Snee M, Waller D, Warburton C, Win T. Guidelines on the radical management of patients with lung cancer. Thorax. 2010; 65(Suppl 3): iii1-iii27.

4. Holohan C, Van Schaeybroeck S, Longley DB, Johnston PG. Cancer drug resistance: an evolving paradigm. Nat Rev Cancer. 2013; 13(10): 714-726.

5. Fulawka L, Donizy P, Halo A. Cancer stem cells - the current status of an old concept: literature review and clinical approaches. Biol Res. 2014; 47(1): 66.

6. Kreso A, Dick JE. Evolution of the cancer stem cell model. Cell Stem Cell. 2014; 14(3): 275-291.

7. Nassar D, Blanpain C. Cancer Stem Cells: Basic Concepts and Therapeutic Implications. Annu Rev Pathol. 2016; 11: 47-76.

8. Itoh $\mathrm{H}$, Nishikawa $\mathrm{S}$, Haraguchi T, Arikawa $\mathrm{Y}$, Hiyama M, Iseri T, Itoh $\mathrm{Y}$, Nakaichi M, Taura Y, Tani K , Itamoto K. Identification of rhodamine 123-positive stem cell subpopulations in canine hepatocellular carcinoma cells. Biomed Rep. 2017; 7(1): 73-78.

9. Atena M, Reza M, Mehran G. A Review on the Biology of Cancer Stem Cells. Stem Cell Discovery. 2014; 4(4): 83-89.

10. Phi LTH, Sari IN, Yang YG, Lee SH, Jun N, Kim KS, Lee YK, Kwon HY. Cancer Stem Cells (CSCs) in Drug Resistance and their Therapeutic Implications in Cancer Treatment. Stem Cells Int. 2018; 2018: 5416923.

11. Gao J, Chen G, He H, Liu C, Xiong X, Li J, Wang J. Therapeutic Effects of Breviscapine in Cardiovascular Diseases: A Review. Front Pharmacol. 2017;8:289.

12. Santini MT, Rainaldi G, Indovina PL. Multicellular tumour spheroids in radiation biology. Int $J$ Radiat Biol. 1999; 75(7): 787-799.

13. Golebiewska A, Brons NHC, Bjerkvig R, Niclou SP. Critical appraisal of the side population assay in stem cell and cancer stem cell research. Cell Stem Cell. 2011; 8(2): 136-147. 
14. Lei Du L, Wang H, He L, Zhang J, Ni B, Wang X, Jin H, Cahuzac N, Mehrpour M, Lu Y, Chen Q. CD44 is of functional importance for colorectal cancer stem cells. Clin Cancer Res. 2008; 14(21): 6751-6760.

15. Yeung TM, Gandhi CS, Wilding JL, Muschel R, Bodmer WF. Cancer stem cells from colorectal cancer-derived cell lines. Proc Natl Acad Sci USA. 2010; 107(8): 3722-3727.

16. Leung EL, Fiscus RR, Tung JW, Tin VP, Cheng LC, Sihoe AD, Fink LM, Ma Y, Wong MP. Non-small cell lung cancer cells expressing CD44 are enriched for stem cell-like properties. PLoS One. 2010; 5(11): e14062.

17. Hardavella G, George R, Sethi T. Lung cancer stem cells-characteristics, phenotype. Transl Lung Cancer Res. 2016; 5(3): 272-279.

18. Todaro M, Francipane MG, Medema JP, Stassi G. Colon cancer stem cells: promise of targeted therapy. Gastroenterology. 2010; 138(6): 2151-2162.

19. Kozovska Z, Gabrisova V, Kucerova L. Colon cancer: cancer stem cells markers, drug resistance and treatment. Biomed Pharmacother. 2014; 68(8): 911916.

20. Kang EJ, Jung $\mathrm{H}$, Woo OH, Park KH, Woo SU, Yang DS, Kim AR, Lee JB, Kim YH, Kim JS, Seo JH. Association of aldehyde dehydrogenase 1 expression and biologically aggressive features in breast cancer. Neoplasma. 2014; 61(3): 352-362.
21. Sarkar A, Konrad Hochedlinger K. The sox family of transcription factors: versatile regulators of stem and progenitor cell fate. Cell Stem Cell. 2013; 12(1): 15-30.

22. Toschi L, Finocchiaro G, Nguyen TT, Skokan MC, Giordano L, Gianoncelli L, Perrino M, Siracusano L, Di Tommaso L, Infante M, Alloisio M, Roncalli M, Scorsetti M, Jänne PA, Santoro A, Varella-Garcia M. Increased SOX2 gene copy number is associated with FGFR1 and PIK3CA gene gain in non-small cell lung cancer and predicts improved survival in early stage disease. PLoS One. 2014; 9(4): e95303.

23. Saigusa S, Tanaka K, Toiyama Y, Yokoe T, Okugawa Y, Ioue Y, Miki C, Kusunoki M. Correlation of CD133, OCT4, and SOX2 in rectal cancer and their association with distant recurrence after chemoradiotherapy. Ann Surg Oncol. 2009; 16(12): 3488-3498.

24. Lu X, Mazur SJ, Lin T, Appella E, Xu Y. The pluripotency factor nanog promotes breast cancer tumorigenesis and metastasis. Oncogene. 2014; 33(20): 2655-2664.

25. Wefers C, Schreibelt G, Massuger LFAG, de Vries IJM, Torensma R. Immune Curbing of Cancer Stem Cells by CTLs Directed to NANOG. Front Immunol. 2018; 9: 1412. 